"This is the peer reviewed version of the following article: [Menzies, G. (2015), Stop the Boats: Do the Ends Justify the Means?. Econ Pap, 34: 229-242. ]which has been published in final form at [

http://dx.doi.org/10.1111/1759-3441.12113 ]. This article may be used for non-commercial purposes in accordance with Wiley Terms and Conditions for Self-Archiving." 


\section{Stop the Boats: Do the Ends Justify the Means?}

\section{Gordon Menzies, UTS ${ }^{1}$}

\section{Abstract}

The Stop the Boats policy towards irregular maritime arrivals (boat people) is to process prospective refugee-status claimants in non-judicial prisons, without the prospect of ultimate Australian abode, with the aim of stopping further boat people coming to Australia. The numbers of people involved to date are small, as are the economic impacts. Stop the Boats appears to succeed on its own terms, but it faces the pitfalls of 'ends justify the means' consequentialist ethics, favoured by economists and others. Chief among these are that there are no obvious moral limits in pursuing desirable ends, such as stopping deaths at sea.

\section{Have we stopped the boats yet?}

It is a striking feature of the contemporary Australian political landscape that all the questions that could be asked about immigration and multiculturalism seem to boil down to asking if we have stopped the boats. The question presumes we have the power to do so though our policies, so Figure 1 shows the numbers of boat people over the last decade or so, with some key policy regimes.

Figure 1: Boat People and the Total Humanitarian Intake

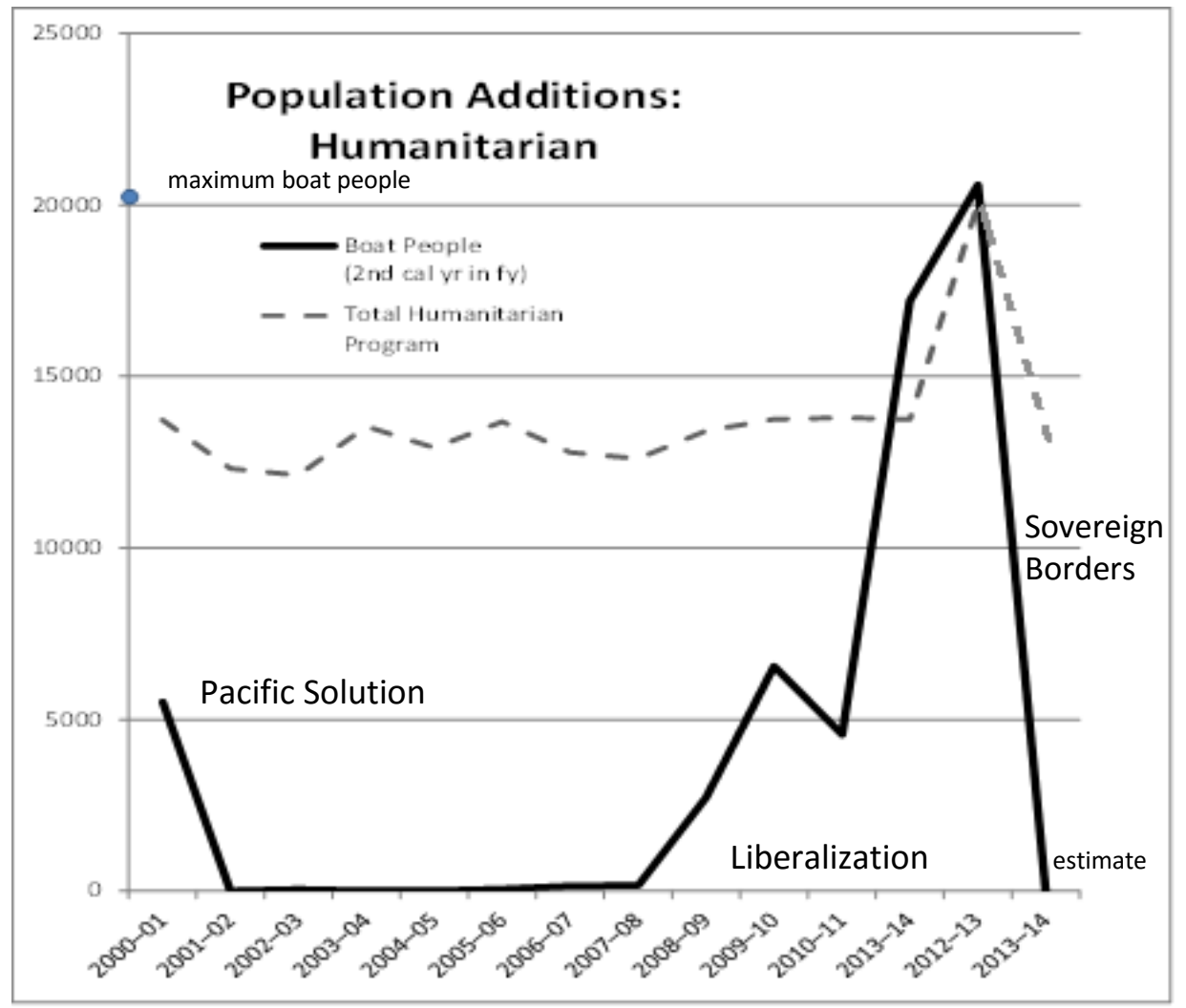

Sources: Figures 1 to 3: Dept Immigration and Citizenship, Dept. Immigration and Border Control, Monash, Parliamentary Library, Refugee Council of Australia.

\footnotetext{
${ }^{1}$ I wish to thank without implication Suyog Sankhe and his colleagues for pointing me in the direction of data; Nhi Tran and James Giesecke for discussions on General Equilibrium theory; Hector Abrahams, Loki Ball, Rod Benson, Scott Higgins, Andrew Leigh, Patrick Parkinson and Phil Waugh for discussions on various ethical and legal issues; The Drum (ABC) for publishing a much-abbreviated summary of this argument 'want to send a message: why not sink the boats', Simon Smart for his input into that article, members of the public who commented on that article, including Alexander Davis and Leigh Youdale, and former students of Global Economy at UTS where we have discussed immigration over a number of years.
} 
The numbers of boat people decreased after the Howard Government implemented the so called Pacific Solution in 2001, where asylum seekers were processed offshore and not guaranteed Australian abode even if found to be genuine refugees. ${ }^{2}$ The first Rudd Government liberalised asylum seeker policy in 2007-08 by announcing the closure of offshore processing facilities, and winding back temporary protection visas. Around the same time, the number of irregular maritime arrivals increased, peaking in 2013 at over 20,000 people. This strained the allocation of visas made available under the Humanitarian Program, which is spread between so called onshore and offshore applicants. During Rudd's second stint as Prime Minister in 2013 a policy was enacted whereby boat people who were successful refugee applicants would ultimately settle in PNG. Later that year, the Abbott Government continued the anti-boat-people stance, effectively forging bipartisan consensus.

Refugee choices are a combination of 'push' and 'pull' factors and many factors that influence these choices originate outside Australia. Indeed policies have often responded to some perceived external crisis. As documented by Menadue et al. (2011) ${ }^{3}$ a surge in worldwide refugee numbers occurred in 2001 and 2002 coinciding with the US wars in Afghanistan and Iraq. ${ }^{4}$ From 2005, when the assassination of the Sri Lankan foreign minister by Tamil Tigers ushered in a state of emergency, to 2009, when the government declared victory in a brutal civil war, there was a build-up in asylum seekers from that country. And in 2007 there was troop surge in Iraq, which created more asylum seekers.

Phillips and Spinks (2013) express doubt that domestic policy could deter asylum seekers based on a number of overseas studies, ${ }^{5}$ but it may be that push and pull factors change in their relative importance the further one is away from the home country. That is, a country like Australia may have greater policy freedoms than, say, Pakistan, which shares a border with Afghanistan. All things considered, the changes in the numbers of boat people in Figure 1 is so well-timed with policy changes, both the increase during liberalization and the recent decline following Sovereign Borders, that it seems hard to deny some kind of deterrent effect. ${ }^{6}$

In the latest version of Stop the Boats, Operation Sovereign Borders, authorities process prospective refugee-status claimants in offshore detention facilities, without the prospect of ultimate Australian abode, with the aim of stopping further boat people from arriving in Australia. Stop the Boats has increasingly enthusiastic proponents on both sides of politics and we may even see a scramble next election to see both sides try to take ultimate credit for a tough policy. So, it may be worthwhile summarizing some of its alleged advantages.

First, stopping boats means stopping sea deaths of unauthorized entrants en route to Australia. Although there is no guarantee that refugees will not undertake hazardous journeys elsewhere, the journey to Australia is a particularly long one, and, if there is a genuine deterrent effect, harsh treatment of early cohorts of refugees discourages risk taking by subsequent ones.

\footnotetext{
${ }^{2}$ To that end the government excised outer islands from Australia, so that asylum seekers who landed there were not technically on Australian soil. In 1999 the Howard government had also introduced temporary protection visas which gave some refugees the right to live in the community, but not permanently. An excellent summary of immigration policy details germane to this paper is Phillips and Spinks (2013).

${ }^{3}$ See their discussion surrounding Graph 5 on page 32.

${ }^{4}$ Their numbers are for the US, UK, other Europe, Canada and Australia. This is approximately a non-Asia OECD grouping.

${ }^{5}$ They claim on page 34 that "there is no credible evidence that the threat of mandatory detention stops people from seeking refuge". Australia's policy involves mandatory detention and the threat of no ultimate Australian abode.

${ }^{6}$ A caveat here is part of Operation Sovereign Borders is a blackout on information so it is difficult to know if many people are in fact setting out, but being turned around.
} 
Second, the policy stops people smugglers earning income from their Australian operations.

Third, it makes the immigration system easier to operate by ensuring claimants are processed in an orderly way.

A fourth advantage claimed, often implicitly, is that deterrence stops claimants who would fail a character test, or so-called economic refugees, coming by sea. It is hard to deny it will stop these groups coming by sea, but as we shall see in the next section there are many other ways in which all sorts of people come to live in Australia. To the extent that these are problems, they are problems of refugee applications in general, not just those of boat people. ${ }^{7}$

Finally, it is electorally popular. Both major parties support it, and stopping the boats may prove to be one of the main electoral assets of the Abbott Government's first term - a simple promise with a simple delivery. It also has appeal for compassionate voters on the Left and Right who may care little for border protection, but who reluctantly support stopping deaths at sea by 'tough' means.

Most of these advantages appeal to the positive consequences of the policy, and sidestep some of the vexing justice issues of how the policy is implemented - in particular, whether Australia has 'crossed a line' of human rights disregard with mandatory detention of boat people. In the remainder of this paper I will therefore organize my material with this distinction in mind.

First, I will refrain from commenting on justice issues or moral principles - what is sometimes called deontological ethics - and speak the language of consequences. This so-called consequentialism is the mainstay of economic analysis and so it is a fitting place to start. Then, in the later sections, I will consider some arguments based on moral principles. $^{8}$ I will commence my discussion of consequences by thinking of an alternative policy of allowing more boat people into Australia, and asking how costly this might be.

\section{What Would be the Economic Consequences of a More Liberal Refugee Policy?}

It is in the nature of sensible policy analysis to consider alternatives to the status quo. As a preliminary step, it is important first of all to understand some basic 'facts and figures'. To this end, Figure 2 shows that the number of boat people is actually quite small relative to the total numbers of immigrants. The main migration program inflow (bold) is approximately ten times the humanitarian program. ${ }^{9}$ This shows the flows, however, and we may wish to look at the stock - the numbers of Australian residents from these different sources cumulated over time. So, in Figure 3, we show the total numbers of person cumulated since 2001 .

\footnotetext{
${ }^{7}$ It seems a little odd to be critical of people pursuing financial advantage when our whole economic system is based on that motive. In any case, refugees are assessed on criteria other than their financial aspirations.

${ }^{8}$ In evaluating the morality of an act, consequentialism focuses on the consequences (colloquially, the 'ends'), deontology focusses on the rightness or wrongness of one's conduct along the way (colloquially, the 'means'). It is an area of active debate among philosophers how far to widen the definition of 'consequences' within consequentialism; in the extreme if they include all means as well as ends, no distinction remains between consequentialism and deontology. For the purposes of this paper, I will define a consequentialist position as one which is blind to any injustice in the treatment of refugees. I accept that one could have a wider definition so that either 'rights violation' or 'maximal justice' registers as a consequence, but I have not chosen to do so. As an example of where I have drawn my line: If you could stop all refugee boats with a perfectly credible threat to sink the first boat and it so happened that the lives of all parties were improved as a result, without having to sink a single boat, then on my definition this policy lacks any consequentialist downside. But it registers a large negative on a deontological criterion since the action threatened is extremely unjust.

${ }^{9}$ The humanitarian program is a set number of visas put aside for people applying on humanitarian grounds, either 'onshore' (in Australia) or 'offshore'. Every visa taken by a boat person comes off the quota; hence the accusations of 'queue jumping'.
} 

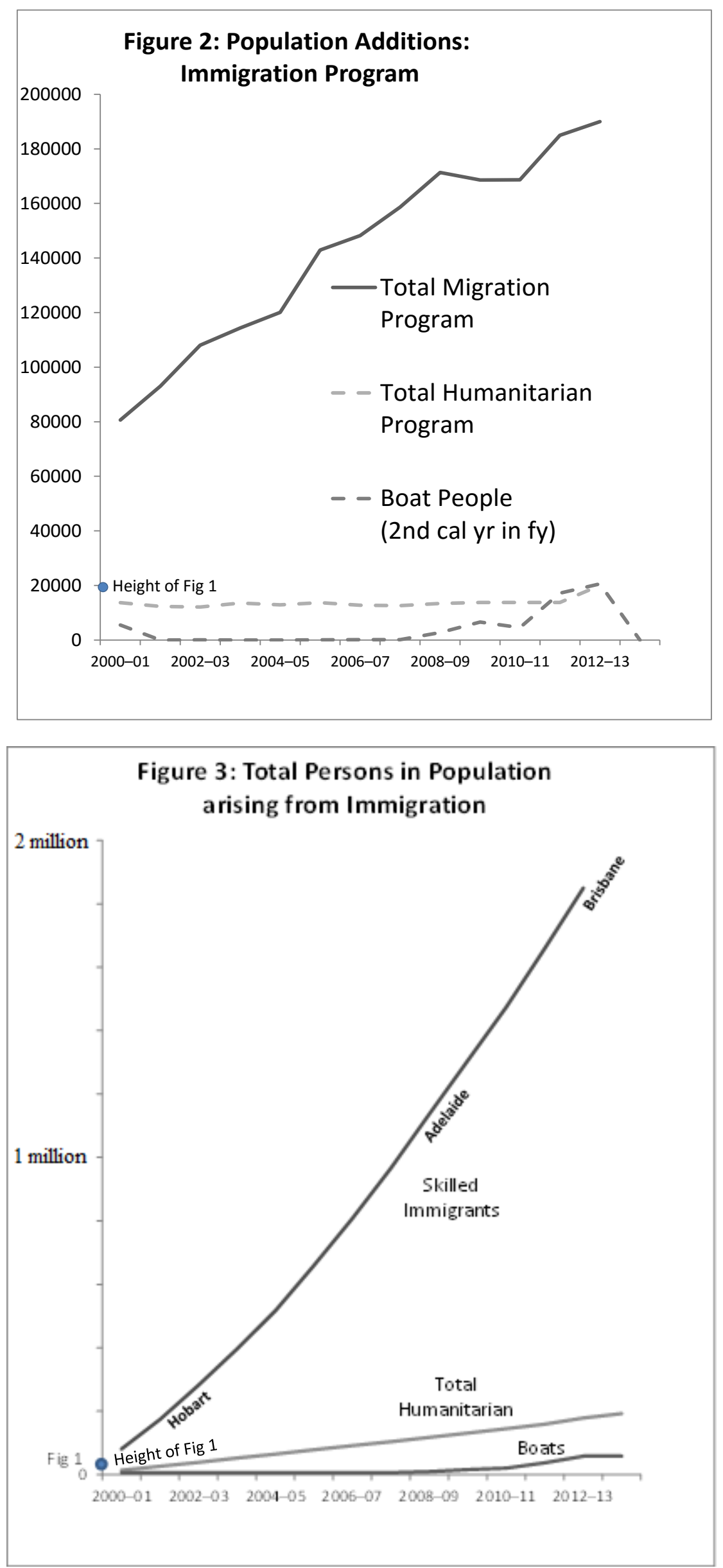
The numbers are extremely large in Figure 3, which has a vertical axis ten times the size of Figure 2, which in turn has a vertical axis ten times Figure 1. To keep perspective the dot registering the height of Figure 1 (the maximum flow of boat people) is kept in Figures 2 and 3. Within three years there were enough general immigrants to create a city the size of Hobart $(200,000)$; within 10 years we could have recreated Adelaide $(1,200,000)$ and over the whole period we are close to being able to recreate Brisbane, with just under two million new arrivals. ${ }^{10}$ In contrast, the number of boat people over the period $(57,000)$ would make for a poor crowd at the MCG $(100,000)$.

The merits or otherwise of this large scale program are beyond the scope of this paper. ${ }^{11}$ The point instead is that any general debates about immigration and immigrants are best had with reference to this large group, and not with reference to boat people. In fact, the relative magnitude of these two programs (humanitarian and general) reframes the whole discussion. Irregular maritime arrivals are not trivial as people, but their effects on the Australian economy and society must be trivial compared with the much larger inflows from other immigration sources. ${ }^{12}$

Coming to terms with the numbers of refugees involved, especially relative to the size of our immigration program, is a crucial ingredient to any consequentialist argument about refugees. It proves to be important in answering the objection that since humanitarian entrants are more costly for the economy, Australia cannot afford to have any more. To explore this question further it will be necessary to stipulate both a 'worst case' difference between the characteristics of a humanitarian visa holder and a skilled migrant, and to imagine some increase in the current humanitarian intake.

\section{The GDP Cost of Switching 120,000 Refugees for 120,000 Skilled Immigrants}

As a thought experiment, suppose that instead of the immigration history we have had Australia had substituted 10,000 extra boat people per annum (compared with an average over the period from 2001 of 5,000 per annum) for 10,000 skilled immigrants. Had that been the case, the number of boat people would be 120,000 higher and the number of skilled immigrants would be lower (i.e. by 120,000). ${ }^{13}$

It is useful to make this offset in the skilled immigrant numbers because it controls for any general effects based solely on the total numbers of new people - the key one being that GDP always goes up when you add any new 'inputs' including productive labour of any kind. That is, the reason I am fixing the total number of people inflows in my thought experiment is not because this is a realistic forecast or even a desirable outcome. Rather, I am just looking at the effect of a more liberal policy without mixing it up with other debates, such as, the desirability of a 'big Australia' or the more general effects of immigration.

\footnotetext{
${ }^{10}$ Naturally, this is not the same as the net addition to population, since we would have to add underlying growth, and subtract death and emigration.

${ }^{11}$ For a relatively recent discussion of the migration debate from an economic point of view, see the interchange between Giesecke (2006 and 2007) and Clarke (2007). Leigh (2014) is also a nice overview.

${ }^{12}$ For example, a humanitarian concerned about the environmental capacity of Australia to carry extra population could nominate any positive immigration level, and advocate for a shift in its composition towards refugees.

${ }^{13}$ It might be objected that thought experiments are the wrong approach. Instead, the first step in any such analysis should be to work out the optimal humanitarian intake, and then the optimal split between numbers of boat people and other humanitarian refugees. In the absence of any national altruism, and assuming that humanitarian refugees have less favourable labour market outcomes than other refugees, it would be hard to imagine a humanitarian program existing at all. That being so, working out an 'optimal amount' will depend on the extent of community altruism, something beyond the scope of this paper. As for the split between boat people and others within a fixed humanitarian total, there is not sufficient data to distinguish the two groups very effectively, possibly because they are very similar.
} 
The subsequent calculation is not to be confused with a calculation of the costs of Australia's mandatory detention system which runs into the billions, ${ }^{14}$ though advocates for the policy are correct that as more refugees eschew the maritime route these costs will fall. Nor is it to be confused with the costs of extra services for refugees, which Leigh (2014) puts at a maximum of $\$ 30,000$ per person, or the costs of any extra welfare payments for refugees. As important as these are politically, many of them could be regarded as transfer payments whereas the calculations undertaken here are about the proverbial 'pie' - the economic wealth that our tax and transfer system is based on.

Transfer payments are important, especially for the current residents who might make them to extra newcomers, but the rules change in response to stresses and challenges, and it is a mistake to imagine that a system would go on indefinitely with any 'extreme' pattern of payments. ${ }^{15}$

So the following exercise simply follows the convention of separating efficiency (the productive potential of the economy) from equity (the fairness or otherwise of financial arrangements between residents). If the GDP costs of a more liberal policy are relatively small, but the strain of the tax-transfer system makes it unworkable, it is always an option for the government to redesign the latter to make it more sustainable in the event that a more liberal policy is pursued.

In Appendix 1 we arrive at a figure of -0.29 per cent of GDP per annum for the switching of 120,000 refugees for the same number of skilled immigrants. If we compound this effect for a generation (40 years), using a 5 per cent discount rate it comes to a one off cost of 5.0 per cent of GDP. It is interesting to compare this loss with the loss arising from a typical adverse commodity price shock on Australia driven, say, by a fall in the iron ore price, were it sustained permanently. Jaaskela and Smith (2011) calculate this to be a very similar magnitude, namely -0.25 per cent of GDP per annum.

That is, a significant reorientation of Australia's immigrant intake towards boat people would require an adjustment equivalent to one of the frequent negative terms of trade shocks Australia receives from commodity prices, sustained permanently. For a country with 23 million people, -0.29 per cent of GDP per annum comes to $-\$ 190$ per person per annum. ${ }^{16}$

The calculations in Appendix One are admittedly crude. But, as Figures 2 and 3 remind us, boat people make up a tiny fraction of the labour force. Even if the modelling were mistaken by a factor of two, the impact on the economy is arguably quite manageable. I conclude that there are numerous obstacles standing in the way of a more liberal immigration policy, but a crippling economic cost is not one of them.

\footnotetext{
${ }^{14}$ The Houston report (Commonwealth of Australia, 2012) outlines proposed expenditure of over $\$ 3$ billion for building, running and maintaining offshore processing in their Attachment 11, which is around 0.2 per cent of GDP ( $\$ 120$ for every person in a population of 23 million).

${ }^{15}$ Regarding welfare payments, it is not easy to have confidence in forecasts of transfer payments over significant time horizons, when something as complex as racial integration occurs. After all, European Australia itself, which began with a publicly funded population unable to pass a character test on today's standards, had a thriving economy within a number of generations.

${ }^{16}$ An anonymous referee pointed out that the thought experiment here does not distinguish between increasing the humanitarian intake via 'boat people' or other humanitarian refugees. The point is well taken. Achieving the same reorientation via non-boat humanitarian refugees may well involve fewer traumas for the incoming people, which is likely to make them more productive once they are employed. On this point my estimates would then be an upper bound, since I am more pessimistic on labour market outcomes than perhaps I need be. I am grateful to Tran et al. (2010) for helping me review some data behind their paper. Unfortunately, it has not been possible to meaningfully distinguish boat from non-boat humanitarian entrants in terms of their labour market outcomes. Given that most boat people are eventually deemed to be genuine refugees, it is possible the two cohorts of people are actually quite similar. On another matter, it is unclear how to calculate the relative costs of arrivals compare between these two groups without having detailed data on so called people smuggling operations and their use of resources.
} 
This calculation does, however, raise the question of whether this would be the case for our regional neighbours.

\section{Regional Consequences}

The fact that Australia pursues such a large immigration intake suggests that its absorptive capacity is quite high. How are other countries in the region placed in this regard? One possible measure of absorptive capacity is the population size relative to the number of immigrants. This is a crude proxy for how impactful the 'new ways' of immigrants are likely to be for the population, especially in a democracy where migrants will eventually vote. A low population size will require the hosts to make more rapid changes, some of which will be seen to be beneficial and enriching, which is after all one of the reasons to be a host country, and some of which will be more of a challenge. Another measure is GDP, which is a crude proxy for the ability to create and sustain infrastructure for the new residents. In Table 2, we compare Australia's absorptive capacity on these two measures with some of the countries involved in (or approached about) refugee processing and resettlement at Australia's instigation.

Table 2: Absorptive Capacity of Australia's Potential Refugee Partners

\begin{tabular}{|l|l|l|}
\hline & Population (nearest $1 / 2$ million) & GDP (\$US billion) \\
\hline Australia & 23 & $\$ 1561$ \\
\hline Cambodia & 15 & $\$ 15$ \\
\hline Malaysia & 30 & $\$ 312$ \\
\hline Nauru & 0.01 & $\$ \quad 0.06$ \\
\hline Papua New Guinea & 7.5 & $\$ 15$ \\
\hline Timor-Leste & 1 & $\$ 2$ \\
\hline
\end{tabular}

Source: World Bank and CIA fact book (Nauru)

Table 2 raises questions about Australia's refugee approach as a regional development policy. Which countries in the region have the greatest absorptive capacity to process and assimilate a group of people with special humanitarian needs? Australia can cushion its partners financially by paying for offshore processing and detention facilities, as it is in fact doing, but the effects of people movements are long lasting and somewhat unpredictable. The table also raises questions about regional power. Which countries in the region are most likely to be keen to appease a powerful and rich neighbour that wants to bequeath a difficult problem to them? Even for voluntary agreements, huge wealth disparities raise the possibility of 'desperate exchanges' for countries, just as they do for individuals.

Table 2 thus raises questions about the scope of consequences we take into account in any analysis of Australia's policy. In particular, why should we only consider consequences within our own nation? If the relative burden of a refugee intake is much higher for other countries in the region, for the reasons given in Table 2, perhaps one refugee sent to one of those countries should count for more in any cost-benefit analysis?

\section{Consequences Ignored so Far}

There is now a large system that has been created to administer Stop the Boats. It involves naval personnel, security staff, parts of the public service and the highest levels of government. This system appears to achieve its objective of stopping the boats, but it also trains its participants in the creation and maintenance of mandatory detention facilities.

It might be surmised that in terms of its effects on the participants this system is like the military or the judicial system, which deal with the extremes of the human condition. It is not unheard of that soldiers or prison officers can suffer trauma, and perhaps Australia will in the future be dealing with 
trauma of those trained to administer this policy. Among them might be people who are in so called helping professions, such as mental health workers, who are effectively working against a system they know is designed to punish - not help - refugees as a form of deterrent.

Defending and administering the policy also involves the government in high-profile violations of the spirit of the law, principles such as avoiding arbitrary imprisonment. This spectre of the government failing to act in good faith regarding legal principles risks eroding the general goodwill of the population - social capital - important for, inter alia, volunteering, charitable giving and tax compliance. It is difficult to know how much this policy will change the tone of Australian society, but a negative effect cannot be ruled out.

Trustworthiness is an elusive thing, but it appears to contribute to a range of important behaviours. For example, although there is no way to force the government of a sovereign nation to pay their debts to those outside their borders, they generally do. Compliance with this international convention occurs even in the absence of an international debt collecting body. One reason offered for this behaviour, among several, is that the poor treatment of outsiders might ruin the government's reputation with those inside its borders (Cole and Kehoe, 1998). ${ }^{17}$

This mention of legal principles is a bridge that takes us towards considering the morality of the means used to Stop the Boats. Before crossing over, however, it is worth asking whether Stop the Boats has been pursued so relentlessly that it almost has the status of a moral principle in itself. That is, just as an opponent of the death penalty might say 'avoid killing people in prison at all costs' would it be fair to say that our government wants to Stop the Boats at any cost?

I have my doubts that Stop the Boats can be thought of moral principle, though I cannot comment on whether it has become this for the government, or some people within it. For a start, moral principles claim a universality which Stop the Boats clearly cannot. You mightn't agree with the maxim 'you should never lie' but it has enough plausibility and coverage that you could have a serious discussion about it, and mount a case for it. Stop the Boats, on the other hand, is nowhere near a universal principle - I haven't myself been on a luxury boat cruise recently, but I am led to believe the government wouldn't stop me leaving the country on a boat like that. My guess is that the more compassionate advocates for the policy, like Leigh (2014), do see it is a means to an end - a 'toughlove' way of managing people movements.

\section{What's in a Name?}

As the community has debated the morality of Stop the Boats, a key flashpoint has been allegations of human rights abuses towards refugees. This was one concern among many in the Houston Review commissioned by the Gillard government:

"There are no quick or simple solutions to the policy dilemmas and the humanitarian challenges that asylum seeking create. In addressing these dilemmas and meeting those challenges, we believe that Australian policy can, and should, be hard headed but not hard hearted; that practicality and fairness should take precedence over theory and inertia; and that the perfect should not be allowed to become the enemy of the good."

(Commonwealth of Australia, 2012, pg. 7)

\footnotetext{
${ }^{17}$ In fairness a point could be made that leads in the other direction. The popular support for Stop the Boats on both sides of politics might suggest that tough immigration policy has become a symbol of the 'trustworthiness' of any government - certainly not in the sense of them honouring international agreements, but in the sense of protecting the community from perceived dangers. The reasonableness of that judgment by the electorate in turn depends upon the reasonableness of their concerns about a more liberal policy.
} 
A cornerstone of Australia's policy is mandatory detention, and there is a fundamental (and politically convenient) confusion about its aims. When originally implemented, the stated aims revolved around creating an orderly and reasonable process for assessing claims (Phillips and Spinks, 2011 ${ }^{18}$ ). As the policy has evolved, however, it has come to be associated with deterrence, and so has acquired a punitive flavour.

As might be expected, there have been criticisms of mandatory detention from organizations like the $\mathrm{UN}$. One concern is how children fare during the implementation of the policy, and another is whether refugees are kept safe while their claims are processed (Guardian, 2014). A fundamental concern is the holding of people in indefinite detention without any substantiated claims of wrongdoing, which appears to violate the UN Covenant on Civil and Political Rights.

"Everyone has the right to liberty and security of person. No one shall be subjected to arbitrary arrest or detention. No one shall be deprived of his liberty except on such grounds and in accordance with such procedure as are established by law."

(UN, 1966, Article 9, Point 1)

Perhaps it is time to change the name of the 'mandatory detention' centres. Australia has moved significantly away from their original goal and in any case the current term of choice is somewhat euphemistic, since 'detention' brings to mind getting into trouble at school, and not being allowed to play with one's friends.

Would it be fair to call them prisons? - liberty is certainly lacking, but unlike the customers of criminal justice system these people have not had their day in court. An internment or concentration camp is another possibility, according to the first part of this dictionary definition (Oxford 1998):

"A place in which large numbers of people, especially political prisoners or members of persecuted minorities, are deliberately imprisoned in a relatively small area with inadequate facilities, sometimes to provide forced labour or to await mass execution."

Entry Concentration Camp

What is so apt here is that the vast majority of boat people are found to be genuine refugees, so had they stayed in their country of origin they may well have been political prisoners or persecuted minorities. How strange that our representatives are unintentionally acting as an agent of the authorities whom the refugees are fleeing, by interning them.

But in any case, the last part of the definition doesn't fit. No one is suggesting that forced labour or executions are an objective - the greater good supposedly achieved here is the deterrence of future boat people. Perhaps a 'non-judicial prison' captures the notion of prison-like treatment, without any strong connection to justice.

\section{Clean the Streets}

One appealing argument in favour of Stop the Boats is its temporary nature. If it is successful, arbitrary detention will be applied to fewer and fewer people, once the boats stop. This is a classic consequentialist line of thinking where indeed 'the ends justify the means' and would have strong appeal to economists, or any other groups who adopt consequentialism as their ethical discourse. If Figure 1 has been interpreted correctly - that is, liberal and tough policies respectively 'start' and 'stop' the boats - then it is a simple matter for a consequentialist to give his or her nod of approval.

\footnotetext{
18 "Mandatory immigration detention for unauthorised arrivals was introduced by the Keating Government in 1992 under the Migration Amendment Act 1992, as part of the codification of migration policy. The rationale given by the then immigration minister, Gerry Hand, was that detention would facilitate the processing of refugee claims, prevent de facto migration and save the cost of locating people in the community." (no pages on web document)
} 
In a helpful and straightforward defence of consequentialism in this context, Leigh (2014, pg. 9) says that the end goal of Stop the Boats is compassionate but '... the approach is harsh even when implemented well'. In other words, compassionate ends justify harsh means.

He also questions the adequacy of invoking moral principles - deontological ethics - in this particular context. He likens it to embracing a maxim 'never set fire to the Australian bush', when a very good case can be made for back-burning. Leigh writes as someone with singularly outstanding academic and policy credentials, but all the same I have a difficulty with comparing consequentialism with deontology based on examples like the bushfire prohibition. The trouble is that every new example seems to change which approach looks best. I also doubt that anyone can completely avoid deontological thinking when it comes to their core values, or worldview.

For example, would anyone seriously countenance a policy of enslaving all boat people currently in detention? Yet if you are prepared to set aside a core value I think I could make a consequentialist argument in favour of it. There have been many forms of slavery in history, and I bet I could design a slavery solution that was benign enough that everyone in detention would embrace it (passing a test of consequentialism) whose only drawback was that it set aside the principle that slavery is wrong. The inmates of our non-judicial prisons might actually prefer to get on with their lives, have their children go to school, be able to work, and know what their future would look like. And of course, it would be an excellent deterrent for future boat people. It is one thing to be morally squeamish about setting fire to the bush, but quite another to legitimize something like slavery.

Perhaps we can make this point another way, by solving another difficult social problem. A consequentialist with a narrow focus on stopping homelessness could propose that police arrest and kill any street people. 'Clean the Streets' comes to mind as a slogan. The incentives at play from then on would be so powerful that the aim of the policy would be achieved. Street people who really did have somewhere to live would return, and those who didn't would find welfare agencies and sympathetic members of the public bending over backwards to help. It goes without saying that the objection to this policy is that it is grossly unjust to kill someone just for living on the streets.

Clean the Streets is compassionate, in a way. Living on the streets can be dangerous, and the change wrought by the policy would spare many people and their families the heartache of bad future outcomes. In fact, if the people saved exceeded the people mistreated, a compassionate consequentialist would be more, and not less, inclined to support the policy. Nor is it any good saying a negative consequence of the policy is that it sets a bad example. If consequentialism is ethical, a good, and not a bad, example is being set.

For Stop the Boats and Clean the Streets a small number of people - perhaps a very small number are sacrificed for the future wellbeing of others. The number is likely to be small because the majority of at-risk people may only need to hear of a few non-judicial prisons or executions (in the case of Clean the Streets) to come around to the desired behaviour. Needless to say, the sacrificed ones would not describe the policy as compassionate. From their vantage point, the treatment received would be outrageously unfair.

The point is that one of the costs of justice in any society - perhaps even the largest cost - is not the cost of running the criminal justice system and the police force, as sizeable as these are. Rather, it is that society 'puts up with' some messy problems that could be 'solved' in a ruthless consequentialist manner. Think of all the problems with social security or criminal justice that could be eliminated if the authorities were free to 'make an example' of a subset of people with an eye mainly on consequences, rather than fairness. Draconian legal systems are based precisely on this notion. In his defence of the Misuse of Drugs Act (Singapore), on the eve of the execution of Australian Van Tuong 
Nguyen, the Singaporean High Commissioner framed his argument mainly in terms of positive consequences (Koh, 2005). ${ }^{19}$

Many Australians are uneasy with Singapore's drug laws, and would not support Clean the Streets. And it is well known that our legal system works according to principles, not just consequences. Criminals, even those who are known to be guilty, are treated better than consequentialism might dictate. Rigid due process, and the right to have one's day in court, trump practicality and cost minimization time after time. Constraints are thought to be part and parcel of what it means to act in an ethical manner, and to offer persons a basic level of respect. A question is whether we are prepared to do for refugees what we do for criminals.

\section{The World's Most Evil Trade?}

No discussion of the morality of refugee policy would be complete without touching on the supposed necessity of destroying the trade of people smuggling, a trade that draws out language usually reserved for terrorists, paedophiles and dictators.

"People smugglers are engaged in the world's most evil trade and they should all rot in jail because they represent the absolute scum of the earth"

Prime Minister Kevin Rudd (ABC, 2009)

A preliminary remark, though, concerns the significance of the word evil. In contemporary culture is not comfortably used of ordinary people or voters. Rather it is reserved for cinema-scale events like the holocaust or September 11. Western culture now seems to process evil in a centrifuge, pushing all the condemnation of the little people's evil out to the edge, where terrorists, paedophiles - and now people smugglers - eke out an existence alongside Hitler.

The victims of what might be called centrifugal vilification inevitably find themselves classified as a different human race, implicitly or explicitly. A Myth of Total Evil can be applied to them. One does not have to grant any approval to the acts of terrorists, paedophiles or dictators to wonder whether the focus on them sometimes goes beyond a genuinely healthy moral outrage. Like all good things perverted, moral outrage can become self-serving. Centrifugal vilification can be a deep-seated, and perhaps unconscious, strategy to create scapegoats and to avoid moral responsibilities.

It is convenient to have a scapegoat now, when Australia is breaking new ground with its pragmatic treatment of asylum seekers. People smugglers are politically useful in this regard. If the government focussed on the dictators or regimes that drive some people to become refugees, it might elicit sympathy for the refugees themselves, and forge a consensus for a more compassionate policy.

People smugglers may be convenient scapegoats, but there is a troubling question surrounding them: what exactly is their crime? It is easy to grant that leaky boats, incompetent crews, extortion or falsehood constitute crimes, but should the act of assisting of refugees seeking asylum itself constitute a crime? Or to ask the question another way, if someone assists a refugee with a good boat, a competent crew, and an accurate description of the dangers, should that be a crime?

In a recent example of well-intentioned people smuggling (the Age, 2014) Judge Mark Dean expressed some doubts on the matter. As he sentenced an Iranian man to a mandatory jail term for arranging for his wife's parents and siblings to be smuggled into the country, he commented that the

\footnotetext{
${ }^{19} \mathrm{He}$ refers to a large decline in drug crime following the introduction of severe penalties in the 1970s. War is also full of consequentialist tales. The first really 'effective' Concentration Camps in the modern era were created in the Boer war, where the British interned civilians, many of whom died, as part of their ultimately successful scorched earth policy.
} 
case was a good example of why mandatory sentencing attracted so much criticism. Speaking of the defendant's decision to help his relatives escape from persecution, he commented that while it was not lawful it was certainly explicable. Well-intentioned people smuggling does not excuse examples that are not well-intentioned, but it does raise the question of why the evil people-smuggler narrative is more important now that it was for escapees from Nazi Germany, or Vietnam in the 1970s.

\section{Conclusion}

I began this paper by making a distinction between those policies that take into account unjust treatment of refugees, and those which do not. The most salient example of the former type, Stop the Boats, does appear to work on its own terms. As shown in Figure 1, the number of irregular maritime arrivals has slowed, and while I have not developed a full econometric model, it is hard to not credit the policy with some influence on the slowing. Furthermore, it is expected that the number of people in detention will decline, with its consequent positive effects on the fiscal position of the Commonwealth.

I suspect that for many people, including policymakers, this will be proof enough of the policy. Furthermore, the compassionate angle - namely that the deterrent effect will discourage many people from undertaking a hazardous voyage - sells the policy to many others who don't necessarily care for border protection. No wonder it is so politically popular.

And yet the detention of people without trial indefinitely - people whose crime is often just taking us at our word on an international agreement - raises fundamental questions about what sort of people we are becoming or what sort of society we are creating. Unlike the 1970s, when the Fraser government dismissed mandatory detention and offshore processing with at best a few minutes cabinet discussion (Eckersley and Fraser 2011) our country has experimented with a range of policies and discovered how well brutality can work. But that is always the dilemma of consequentialism. What happens when unethical acts achieve their desired ends, and everyone can see it?

Although more detailed modelling could be attempted, it seems pretty clear that the economic costs of receiving more humanitarian refugees are small and manageable, because the numbers of people are low both absolutely and compared to the whole immigration program. Furthermore, Australia is a wealthy country, both absolutely and relatively to others in our region. It would seem that if any country were in a position to create a policy that is both principled and effective, it should be us.

But if that is not so, and there is no alternative to the current arrangements, then perhaps our representatives should remove Australia's signature from the relevant UN documents, both as a deterrent to refugees, and as a matter of national honor. 


\section{Appendix: GDP Calculations for Switching 120,000 Refugees for 120,000 Skilled Immigrants}

In these calculations we make a number of very pessimistic assumptions about the characteristics of boat people compared with skilled immigrants. This is not to denigrate the refugees themselves, but it is just in the nature of thought experiments to sometimes take worst-case scenarios. Our main purpose is to see how bad a worst case scenario could be. ${ }^{20}$

We use the data sources of Tran et al. (2010) as we convert persons into effective labour units. ${ }^{21}$ In Table 1, we begin with the numbers of hours by which migrant and humanitarian labour change (col. 1). The sum of these two numbers is zero, as we just outlined, to control for any effects related purely to numbers of persons.

We then make a series of worst-case assumptions which altogether imply that a cohort of humanitarian refugees contributes roughly half as much labour input as a cohort of skilled migrants of the same size. In constructing the calculations in Table 1 the objective has been to err on the pessimistic side, and to make the calculations numerically straightforward. For example, by assuming workers work 50 weeks per year rather than the more usual 48 weeks, we make the replacement of a skilled worker by a boat person as costly as possible. The other stylized assumptions are:

1. Refugee cohorts are younger: only 60 per cent of them are of an age to work compared with 70 per cent of skilled migrants.

2. Employability is lower for the refugee cohort: of those old enough to work, only 50 per cent will find employment compared with 75 per cent of skilled migrants.

3. All effective employment units (people in working age population with jobs) in Table 1 work a 40 hour week, earning $\$ 40$ per hour, and work 50 weeks per annum. ${ }^{22}$

4. GDP is assumed to be $\$ 1.5$ trillion and labour's share is 50 per cent of that. ${ }^{23}$

Table 1: GDP Effects of Replacing Skilled Immigrants by Refugees

('000, c stands for col)

\begin{tabular}{|c|c|c|c|c|c|c|c|c|c|}
\hline & $\begin{array}{c}\text { People } \\
(\mathrm{n})\end{array}$ & WAP/n & $\begin{array}{c}\text { WAP } \\
\mathrm{c1} \text { c2 }\end{array}$ & $\begin{array}{c}\text { Empl } \\
\text { rate }\end{array}$ & $\begin{array}{c}\text { Empl } \\
\mathrm{c3} \text { c4 }\end{array}$ & $\begin{array}{c}\text { Wage } \\
\text { ph }\end{array}$ & Hrs pa & $\begin{array}{c}\% \Delta \mathrm{L} \\
\mathrm{c5} \mathrm{c6} 7 / \\
1.5(.5) \$ \text { tril }\end{array}$ & $\begin{array}{c}\% \Delta \text { gdp } \\
0.5 \mathrm{c} 8\end{array}$ \\
\hline Skilled & -120 & $70 \%$ & -84 & $75 \%$ & -63 & 40 & $40(50)$ & $-0.672 \%$ & $-0.336 \%$ \\
\hline Refugee & 120 & $60 \%$ & 72 & $50 \%$ & 36 & 40 & $40(50)$ & $+0.384 \%$ & $+0.192 \%$ \\
\hline Net effect & & & & & -27 & & & $-0.288 \%$ & $-0.144 \%$ \\
\hline
\end{tabular}

Columns 1 to 3 multiply persons by the ratio of working age population (WAP) to persons, to give the available workers in each cohort. Then, columns 4 and 5 convert these into numbers of people employed. We can see at this stage that the number of working persons is a bit over half for the refugees. The next three columns turn these people into labour value units by multiplying by the wage

\footnotetext{
${ }^{20}$ Having said that, any randomly selected group, even those who had not had to suffer the horrors of persecution or war, would probably score below a group specifically selected for their skills.

${ }^{21}$ They, in turn, rely on the the Expanded Confidentialized Unit Records files for the Characteristics of Recent Migrants survey, conducted in November 2010 (ABS 2011). The conversion is necessary because 'The model recognizes that annual hours worked per person differ across visa types, skill categories, age groups, occupations and regions.' Tran et al. (2010,pg. 19). This section has benefited from discussion with these authors at the Centre of Policy Studies, but they are in no way responsible for the calculations that follow. 22 The pessimism about refugee labour market prospects are loaded into assumption 2. Equivalently, I could have had a lower hourly wage for them in assumption 3 and a higher employment rate in assumption 2.

${ }^{23}$ Labour's share is higher than this, approaching 55 per cent, but the figure in the text is pessimistic, because it implies a greater long run flight of capital.
} 
rate, then by the hours per annum. In column 8 , the change in labour value is divided by the value of labour input in GDP (income basis) to obtain an estimate of the proportional change in labour input in a simple production function. Finally, in column 9, we assume a labour input in a Cobb-Douglas function of one half, so that $\alpha$ in equation (1) and the column is 0.5 .

$$
G D P=L^{\alpha} \text { Capital }^{1-\alpha} \quad \Leftrightarrow \quad \% \Delta G D P=\left.\alpha \% \Delta L\right|_{\text {fixedCapital }}
$$

As well as our generally pessimistic assumptions, there are other good reasons to take the lost GDP of under 0.15 per cent in the bottom right-hand corner as an upper bound. First, the immediate impact on employment of a cohort arriving with a relatively large number of underage persons will not be the ultimate impact. Strictly speaking, it is the net present value of the labour supplied over all future periods that should be relevant, and this in turn depends on the numbers of children born subsequently. If boat people come from cultural groups with higher numbers of children the net present value of the addition to working persons might be larger than skilled migrants, though this does depend on some imponderable demographic assumptions. Second, one of the limits of GDP measures is that they ignore non-market activities, and so persons technically unemployed may be involved in community/home contributions that are missed in Table 1.

Going in the other direction - towards a larger effect - the economic forces of globalization are relevant for the narrative of Table 1 over time. From column 5 it is clear that the net outcome of this replacement of skilled migrants by humanitarian refugees would have been a smaller effective labour force over this period. An outcome (or perhaps an objective) of skilled migration is to transfer any scarcity rent that might otherwise accrue to labour because of skill shortages to capital, so in this alternative history where there wasn't as much skilled immigration the lower effective workers (column 5) would have implied that labour would have been better off and capital worse off. That is, the loss of effective labour units would have been accompanied by higher wages and lower returns to capital compared with actual history. In a globalized world, this could not have been sustained. Assuming that the real return on capital is determined overseas, and that the economy is constant to returns to scale, then capital would have been lower by the same proportion as labour as foreigners refrained from investing. Since in Table 1, effective labour would have been -0.288 per cent lower, capital would have been lower by the same amount, though it might have taken some time for foreign investors to pull their capital out. For a constant returns to scale economy, the whole economy would have been smaller by the proportional fall in labour (-0.288 per cent in our simulation) and this is our upper bound pessimistic scenario. ${ }^{24}$

\footnotetext{
${ }^{24}$ It should now be clear why the 50 per cent share of labour in GDP is pessimistic. For a given change in effective workers (-27,000 in Table 1) the proportional change in the effective labour force is lower, the higher the assumed share of labour in GDP. Had we assumed 55 per cent in Table 1, the fall in the labour force, and hence the long run fall in labour, capital and output would have been -0.26 per cent.
} 


\section{References}

ABC (2009), 'Rudd wants people smugglers to "rot in hell"', $A B C$ News, correspondent Emma Rogers, 17 April.

ABS, (2011) Characteristics of recent migrants, Nov 2010, Cat. No. 6250.0, retrieved 19 October 2011.

the Age, (2014), 'Judge questions mandatory people-smuggling sentences', The Age, correspondent Adam Cooper, March 11.

Cole, H. and P. Kehoe (1998), 'Models of Sovereign Debt: Partial versus General Reputations', International Economic Review 39(1): 55-70.

Commonwealth of Australia, (2012), Report of the Expert Panel on Asylum Seekers, Chair: A Houston, August 2012.

Clarke, H. (2007), 'Comment on James Giesecke: The Economic Impact of a General Increase in Skilled Migration', People and Place, 15(2), 61-63.

Eckersley, R., and M. Fraser (2011), 'Malcolm Fraser: We Have Lost Our Way', The Conversation, 10 October.

Giesecke, J. (2006), 'The Economic Impact of a General Increase in Skilled Migration', People and Place, 14(3), 48-63.

Giesecke, J. (2007), 'Comment on Harry Clarke on the Economic Effects of Skilled Migration', People and Place, 15(2), 64-71.

Guardian, (2014), 'UN human rights commissioner to call for review of PNG offshore processing', Oliver Laughland, Wednesday 5 March 2014.

Jaaskela, J. and P. Smith, (2011), 'Terms of Trade Shocks: What Are They and What Do They Do? Research Discussion Paper, Reserve Bank of Australia, 2011-05, Sydney.

Koh, J. (2005), 'Separating Fact from Fiction, Despite a Deep Sense of Human Compassion', Sydney Morning Herald, 30 November 2005.

Leigh, A. (2014), 'Does Size Matter? An Economic Perspective on the Population Debate', speech at Lowy Institute 13 March 2014, and subsequently printed in Policy, 30(1), Autumn.

Menadue, J. Keski-Nummi, A. and K. Gauthier, (2011), 'A New Approach: Breaking the Stalemate on Refugees and Asylum Seekers', Centre for Policy Development, August.

Oxford (1998), The New Oxford Dictionary of English, Oxford.

Phillips, J. and Spinks, H., (2013), 'Immigration Detention in Australia', Parliamentary Library, 20 March.

Stott, J. (2006), Issues Facing Christians Today, $4^{\text {th }}$ edition, Zondervan, Michigan.

Tran, N., Roos, L. and J. Giesecke (2012), 'DIAC-TERM: A Multi-regional Model of the Australian Economy with Migration Detail' , Centre of Policy Studies and Impact Project ,General Paper G-238, July 2012.

United Nations, (1966), International Covenant on Civil and Political Rights, General Assembly resolution 2200A (XXI) of 16 December 1966 entry into force 23 March 1976, in accordance with Article 49. http://www.ohchr.org/en/professionalinterest/pages/ccpr.aspx 